\title{
Reviewing Municipal Energy System Planning in a Bibliometric Analysis: Evolution of the Research Field between 1991 and 2019
}

\author{
Jann Michael Weinand (D) \\ Chair of Energy Economics, Institute for Industrial Production, Karlsruhe Institute of Technology, \\ 76187 Karlsruhe, Germany; jann.weinand@kit.edu; Tel.: +49-721-608-444-44
}

Received: 14 February 2020; Accepted: 12 March 2020; Published: 15 March 2020

\begin{abstract}
In the context of the energy transition, energy system planning is becoming increasingly relevant for decentralized systems. Motivated by the strong increase of publications on municipal energy system planning (MESP), these studies are subjected to a bibliometric analysis in this paper. The 1235 articles, which are based on the Web of Science database, are examined using the R-tool bibliometrix. The study shows that China is the most important contributor with 225 articles, followed by the USA (205) and Germany (120). Most cross-country collaborations were conducted between China and Canada, focusing mainly on uncertainties in MESP. Among the institutions, the North China Electric Power University is responsible for most articles (42). The core journals on MESP are Energy, Applied Energy, Energy Policy, Energies and Renewable Energy, which published 37\% of the 1235 articles. Publications on MESP focus on renewable energies, optimization and hybrid energy systems. Furthermore, district heating seems to be a core topic in MESP and is addressed in three of the top five most cited articles. The demonstration of global research trends in MESP can support researchers in identifying the relevant issues regarding this expanding and transforming research area.
\end{abstract}

Keywords: bibliometric analysis; municipal energy system planning; research trends; renewable energies; optimization; energy transition; district heating; hybrid energy system; energy storage

\section{Introduction}

In 2015, 197 countries agreed on the Paris Climate Convention, which includes limiting global warming to below $1.5{ }^{\circ} \mathrm{C}$ and reducing greenhouse gas emissions [1]. To achieve this objective, a decarbonization of the energy system is necessary. The increase of the share of low-emission renewable energy in the energy mix could contribute to the decarbonization. In fact, the global capacity of renewable electricity has increased steadily in the past years: from 1.14 TW (2009) to 2.36 TW (2018) [2]. The expansion of renewable energy sources is mainly decentralized due to their characteristics. Therefore, municipal energy system planning (MESP) becomes more and more relevant. MESP means that the municipalities are becoming involved in energy system planning: they increasingly own and operate decentralized renewable energy systems and their energy demands are less covered by centralized plants. In Germany, for example, the majority of regenerative plants are actually owned and operated by private individuals, farmers and communities [3]. As a consequence, the number of municipal energy projects is increasing (e.g., energy cities [4]) and in 2016, there have already been 2400 energy cooperatives in Europe [5]. Furthermore, the voluntary agreement of many local governments of towns, cities and regions (mainly European) in the Covenant of Mayors has also shown strong local support for the active involvement in sustainable energy planning since it started in 2008. Thereby, it has been demonstrated that municipalities can become a significant factor in the political decision process for energy planning and sustainable development [6]. At the end of 
2018, the European Covenant of Mayors initiative covered about 7850 local authorities and 250 million inhabitants [7], with $66 \%$ of the local authorities having less than 10,000 inhabitants [8].

Given this great potential to contribute to decarbonization, the number of studies on energy system planning at the municipal level has also increased significantly since 1991 (cf. Section 3). These studies are necessary to support municipal decision-makers in energy system planning, since they often have limited expertise in this area. Hence, it becomes necessary to investigate the growing body of literature. For this purpose, various quantitative and qualitative literature review approaches are used by researchers to understand and organize findings from existing studies. Among these approaches, bibliometric analysis has the potential to provide a systematic, reproducible and transparent review process, based on statistical measurements of research activities and researchers [9]. Therefore, this type of review can be classified as more objective and more reliable than traditional review methods. By providing a structured analysis to the large body of information on MESP, the bibliometric review in this study can meet the following objectives [9]:

- infer trends over time

- show themes researched

- identify shifts in the boundaries of the disciplines

- detect most prolific scholars, institutions and countries

- present an overview of the extant research

These objectives should be achieved with the present review study on MESP. To this end, the article is organised as follows: Section 2 describes the most important methodological aspects of this study. The results and limitations of the bibliometric analysis are then presented in Section 3. Subsequently, Section 4 provides a summary and conclusions of the paper.

\section{Methodology}

In bibliometric analyses, a document system, together with the bibliometric characteristics of the individual documents, is taken as the research object. Mathematical and statistical methods are employed to explore the structure, characteristics and patterns of the underlying science [10].

The literature database Web of Science and the R-tool bibliometrix [9] are used to investigate the literature on MESP. Firstly, the development as well as the cooperation of the most important countries, institutions and authors on MESP should be presented. In addition, the most relevant journals and publications are subjects of the analysis. In order to get an overview of the thematic development of MESP, the most important subjects are also explained and discussed. In Web of Science, the adjusted search query in Table 1 is used: on the one hand, the articles should contain energy system planning. Different methods like optimization or analysis are thereby equated with planning. In addition to municipalities, the search query contains other similarly associated terms such as communities, district or cities. The reason for this is that similar conditions (such as the number and type of stakeholders) apply to these spatial territories. Finally, the results are limited to original research articles and to the English language.

Table 1. Search queries and resulting number of articles in the literature database Web of Science.

\begin{tabular}{|c|c|c|c|}
\hline Search Name & Search Query & Date & Number of Studies \\
\hline Initial search & 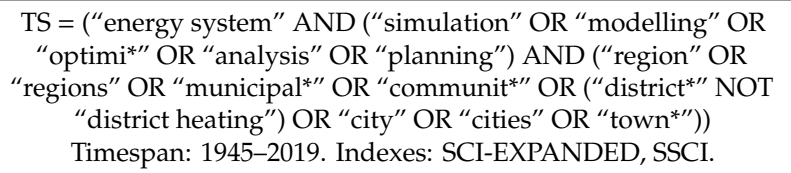 & 04.03 .2020 & 1346 \\
\hline Adjusted search & 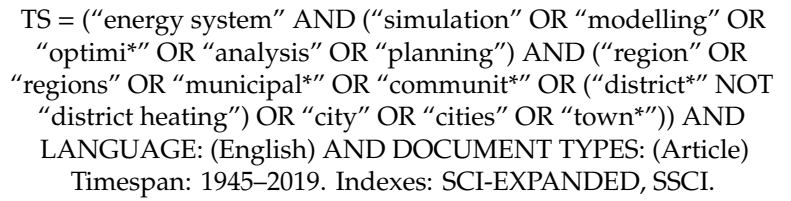 & 04.03 .2020 & 1235 \\
\hline
\end{tabular}


Table 1. Cont.

\begin{tabular}{|c|c|c|c|}
\hline Search Name & Search Query & Date & Number of Studies \\
\hline $\begin{array}{l}\text { Energy system } \\
\text { planning search }\end{array}$ & $\begin{array}{c}\text { TS = ("energy system" AND (“simulation" OR “modelling" OR } \\
\text { “optimi*” OR "analysis” OR “planning")) AND LANGUAGE: } \\
\text { (English) AND DOCUMENT TYPES: (Article) } \\
\text { Timespan: 1945-2019. Indexes: SCI-EXPANDED, SSCI. }\end{array}$ & 04.03 .2020 & 5778 \\
\hline
\end{tabular}

In addition to the bibliometric analysis tool bibliometrix (Section 2.1), the statistical indicator h-index (Section 2.2) is explained in the following.

\subsection{R-tool Bibliometrix}

Whilst the main part of the analysis is based on manual evaluations and calculation of metrics such as the h-index, the R-tool bibliometrix is also used to examine the corpus of literature. It is an open-source tool for performing comprehensive science mapping analysis. By implementing it in R, the package is flexible and facilitates integration with other statistical or graphical packages [9]. Some examples for which bibliometrix was used are the country collaboration map (cf. Figure 1) or the number of collaborative publications (cf. Section 3.2).

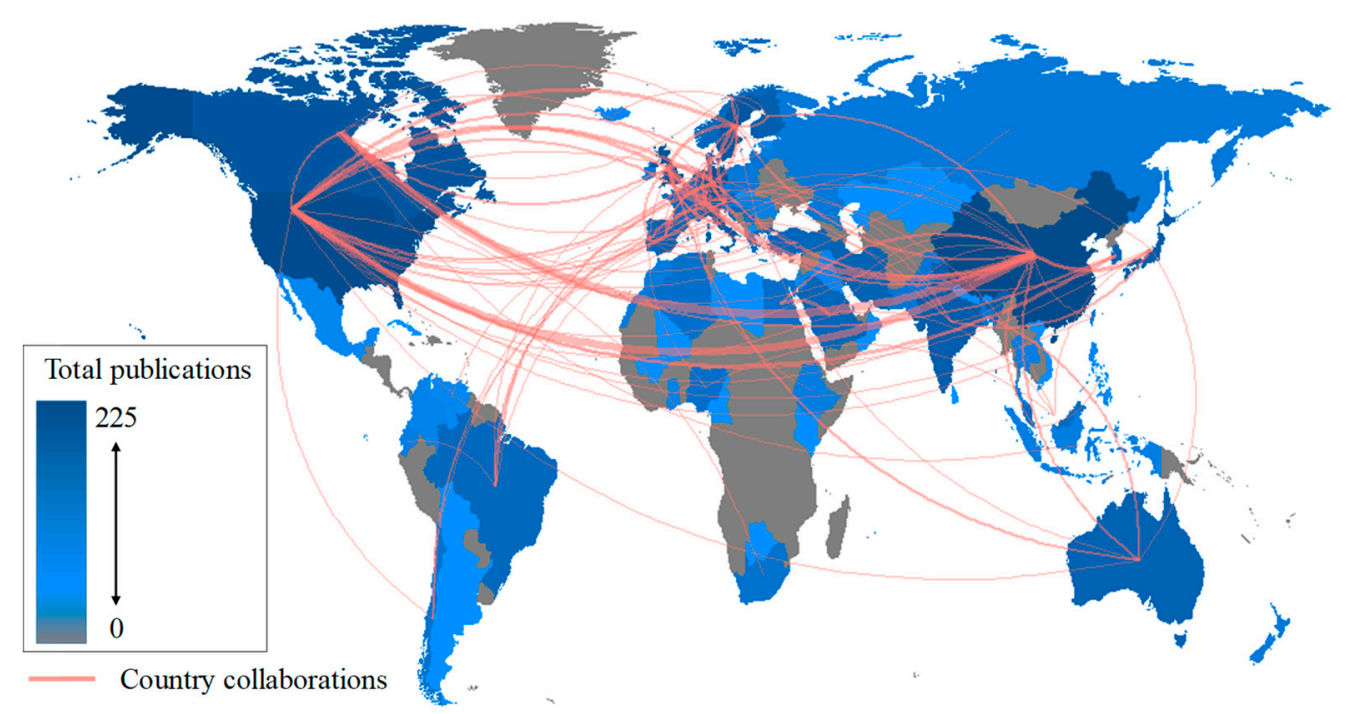

Figure 1. World map collaboration on municipal energy system planning. The blue gradient shows the number of publications and the red lines represent collaborations between countries. The illustration was in part created with the R-tool bibliometrix [9].

\subsection{Measure of Influence: $h$-Index}

The h-index was introduced to help quantify the cumulative impact and relevance of an individual's scientific output [11]. Thereby, an individual is associated to publications and can therefore be an author, institution, country or journal. The h-index represents the number of $h$ papers of an individual that have been cited at least $h$ times. For example, if 10 publications of an author have been cited at least 10 times, then that author's h-index is 10 . The h-indexes presented in this article refer only to the analyzed studies on MESP. This is to ensure that only the influence within this specific research field is shown, rather than the general scientific influence of an individual.

\section{Results and Discussion}

The initial search query on 04.03 .2020 in Table 1 found 1346 results. Among these publications are 1241 original research articles, 100 review studies, 93 proceedings papers, three editorial materials, two early access publications, as well as one publication each for data papers, letters and notes. Six of 
the 1241 articles are written in German (2), Spanish (2), Polish (1) and Russian (1). The vast majority (1235 English articles, see adjusted search in Table 1) are used as the basis for the present analysis.

In the following, the main characteristics of the research field are presented (cf. Section 3.1). Afterwards, an overview of contributions and collaborations of different countries and institutions is given in Section 3.2. Subsequently, the most relevant sources, authors, studies and references are highlighted (cf. Section 3.3), before the most relevant topics on MESP are discussed (cf. Section 3.4). Finally, the limitations of this study are discussed in Section 3.5.

\subsection{Development of the Research Field}

Some developments in the research field of MESP between 1991 and 2019 are shown in Table 2. The number of publications has fluctuated over the years, but there is a clear trend: the number is growing exponentially, and between 2013 and 2019, grew by 33\% per year on average. This increase could be related to the development of renewable energies (as mentioned in Section 1), which is further underlined by specific examples in Section 3.2.

Table 2. The development of scientific publications on municipal energy system planning between 1991 and 2019.

\begin{tabular}{|c|c|c|c|c|}
\hline Year & Total Publications (TP) & Authors per TP & References per TP & Pages per TP \\
\hline 1991 & 1 & 3.0 & 17.0 & 15.0 \\
\hline 1992 & 4 & 1.8 & 8.3 & 9.8 \\
\hline 1993 & 1 & 3.0 & 20.0 & 15.0 \\
\hline 1994 & 5 & 4.0 & 9.2 & 12.0 \\
\hline 1995 & 1 & 4.0 & 22.0 & 10.0 \\
\hline 1996 & 3 & 2.7 & 8.3 & 9.0 \\
\hline 1997 & 4 & 1.5 & 25.3 & 14.3 \\
\hline 1998 & 4 & 1.8 & 26.3 & 11.0 \\
\hline 1999 & 2 & 4.0 & 3.0 & 12.0 \\
\hline 2000 & 8 & 4.1 & 18.4 & 13.4 \\
\hline 2001 & 5 & 3.6 & 23.4 & 12.4 \\
\hline 2002 & 8 & 3.0 & 27.1 & 11.6 \\
\hline 2003 & 7 & 3.4 & 24.9 & 7.9 \\
\hline 2004 & 13 & 2.9 & 23.8 & 13.7 \\
\hline 2005 & 13 & 5.3 & 32.1 & 14.6 \\
\hline 2006 & 15 & 2.8 & 27.2 & 14.2 \\
\hline 2007 & 16 & 2.9 & 24.3 & 12.9 \\
\hline 2008 & 23 & 3.2 & 29.0 & 11.3 \\
\hline 2009 & 23 & 3.3 & 29.8 & 10.8 \\
\hline 2010 & 33 & 3.6 & 32.6 & 10.1 \\
\hline 2011 & 35 & 3.4 & 36.3 & 10.9 \\
\hline 2012 & 56 & 3.5 & 34.0 & 12.7 \\
\hline 2013 & 52 & 4.0 & 38.8 & 10.7 \\
\hline 2014 & 77 & 3.8 & 42.4 & 12.6 \\
\hline 2015 & 88 & 3.5 & 46.6 & 12.5 \\
\hline 2016 & 136 & 4.0 & 48.2 & 11.9 \\
\hline 2017 & 142 & 4.0 & 53.9 & 12.2 \\
\hline 2018 & 184 & 4.3 & 52.2 & 11.8 \\
\hline 2019 & 276 & 4.2 & 51.4 & 9.5 \\
\hline
\end{tabular}

Similar developments apply to the number of authors and references per article. While the number of authors seems to stabilize at around four authors, the number of references is constantly increasing. This indicates an increased communication in the MESP research field. The constant expansion of the research field could be related to the generally increasing research worldwide. However, this can be rebutted by the development of the share of publications on MESP in the overall energy system planning literature (cf. energy system planning search in Table 1): between 1991 and 2019, the share 
has increased from 4.3\% to 21.4\% (1 out of 23 (1991) to 1235 in 5778 (2019)). Energy system planning at municipal level is therefore becoming increasingly relevant. This is likely also related to the increased decentralized expansion of renewable energies in recent years (cf. Section 1).

\subsection{Publication Distribution of Countries and Institutions}

Since 1991, authors from 87 different countries have contributed to articles on MESP. This represents a share of $44 \%$ of the 197 countries that agreed to the Paris Climate Convention in 2015 (cf. Section 1). The top 20 most relevant countries (cf. Table 3) account for a large part (86\%) of scientific production, with 1001 of 1235 publications. Among these countries, eleven belong to Europe, six to Asia, two to North America and one to Oceania.

Table 3. The top 20 of the most productive countries in terms of publications on municipal energy system planning. The numbers for "total publications" do not have to sum up to 1235 or $100 \%$, since more than one country could have contributed to a single publication. The percentages for "total publications" and "corresponding author's country" refer to the total number of 1235 articles, while for "single publication" and "collaborative publication" they refer to the number of publications of "corresponding author's country".

\begin{tabular}{|c|c|c|c|c|c|c|c|c|c|c|c|}
\hline \multirow[t]{2}{*}{ Country } & \multicolumn{2}{|c|}{$\begin{array}{c}\text { Total } \\
\text { Publications }\end{array}$} & \multirow[t]{2}{*}{ h-index } & \multirow{2}{*}{$\begin{array}{c}\begin{array}{c}\text { Total } \\
\text { Citations }\end{array} \\
\text { No. }\end{array}$} & \multirow{2}{*}{$\begin{array}{c}\begin{array}{c}\text { Average } \\
\text { Article } \\
\text { Citations }\end{array} \\
\text { No. }\end{array}$} & \multicolumn{2}{|c|}{$\begin{array}{l}\text { Corresponding } \\
\text { Author's Country }\end{array}$} & \multicolumn{2}{|c|}{$\begin{array}{l}\text { Single Country } \\
\text { Publication }\end{array}$} & \multicolumn{2}{|c|}{$\begin{array}{l}\text { Collaborative } \\
\text { Publications }\end{array}$} \\
\hline & No. & $\%$ & & & & No. & $\%$ & No. & $\%$ & No. & $\%$ \\
\hline China & 225 & 18 & 28 & 2673 & 11.9 & 185 & 15 & 97 & 52 & 88 & 48 \\
\hline USA & 205 & 17 & 33 & 3964 & 19.3 & 136 & 11 & 99 & 73 & 37 & 27 \\
\hline Germany & 120 & 10 & 24 & 2079 & 17.3 & 91 & 7 & 69 & 76 & 22 & 24 \\
\hline $\begin{array}{l}\text { United Kingdom } \\
\text { (UK) }\end{array}$ & 94 & 8 & 26 & 1957 & 20.8 & 66 & 5 & 44 & 67 & 22 & 33 \\
\hline Canada & 90 & 7 & 21 & 1571 & 17.5 & 51 & 4 & 31 & 61 & 20 & 39 \\
\hline Sweden & 81 & 7 & 25 & 1910 & 23.6 & 61 & 5 & 44 & 72 & 17 & 28 \\
\hline Italy & 60 & 5 & 18 & 867 & 14.5 & 45 & 4 & 36 & 80 & 9 & 20 \\
\hline India & 56 & 5 & 15 & 1078 & 19.3 & 43 & 3 & 37 & 86 & 6 & 14 \\
\hline Japan & 56 & 5 & 18 & 830 & 14.8 & 46 & 4 & 34 & 74 & 12 & 26 \\
\hline Denmark & 55 & 4 & 21 & 2049 & 37.3 & 38 & 3 & 28 & 74 & 10 & 26 \\
\hline Switzerland & 47 & 4 & 20 & 1224 & 26.0 & 34 & 3 & 16 & 47 & 18 & 53 \\
\hline Finland & 44 & 4 & 17 & 976 & 22.2 & 38 & 3 & 30 & 79 & 8 & 21 \\
\hline Austria & 39 & 3 & 16 & 769 & 19.7 & 23 & 2 & 15 & 65 & 8 & 35 \\
\hline Australia & 34 & 3 & 10 & 471 & 13.9 & 16 & 1 & 12 & 75 & 4 & 25 \\
\hline Iran & 33 & 3 & 13 & 500 & 15.2 & 29 & 2 & 22 & 76 & 7 & 24 \\
\hline South Korea & 33 & 3 & 11 & 434 & 13.2 & 22 & 2 & 14 & 64 & 8 & 36 \\
\hline Spain & 32 & 3 & 13 & 618 & 19.3 & 20 & 2 & 11 & 55 & 9 & 45 \\
\hline Netherlands & 31 & 3 & 15 & 687 & 22.2 & 24 & 2 & 12 & 50 & 12 & 50 \\
\hline Saudi Arabia & 26 & 2 & 7 & 193 & 7.4 & 17 & 1 & 8 & 47 & 9 & 53 \\
\hline Croatia & 25 & 2 & 13 & 540 & 21.6 & 16 & 1 & 9 & 56 & 7 & 44 \\
\hline
\end{tabular}

The first column in Table 3 and the blue color gradient in Figure 1 show the total number of publications in which authors from the specific countries participated. Authors from China (225 publications) and USA (205 publications) were involved in most of the publications. The increase (cf. Figure 2a) of the number of publications in the various countries since 1991 could be related to the development of renewable energies (cf. Section 1): in 2005, when the first law to foster renewable energies in China (Renewable Energy law [12]) was enacted, only six articles on MESP had been published by Chinese authors. Since the municipal specific policy decision Implementation Plan for the Construction and Applications of Renewable Energy in Demonstration Cities in 2009 [12], the annual number of publications has increased by $46 \%$ on average each year. Germany is another interesting example: the energy transition has been accelerated by the nuclear phase-out decision in 2011 following the reactor accident in Fukushima [13]. As a result, the bridging technology nuclear energy no longer applied to the energy transition and alternative technologies became increasingly necessary. Since 2012, at least two articles on MESP have been published each year by German authors and the total number has increased from ten articles in 2011 to 120 articles in 2019. Unlike in the USA, the annual number of articles by Chinese and German authors does not fluctuate but increases steadily (cf. Figure 2a). 
Following the h-index, the most relevant publications on MESP come from the USA with 33 publications with at least 33 citations, followed by China (28) and United Kingdom (26). In contrast, Denmark has by far the highest average citation rate (37), followed by Switzerland (26) and Sweden (24). As Section 3.3 will show, the most relevant publications also come from Denmark.

a)

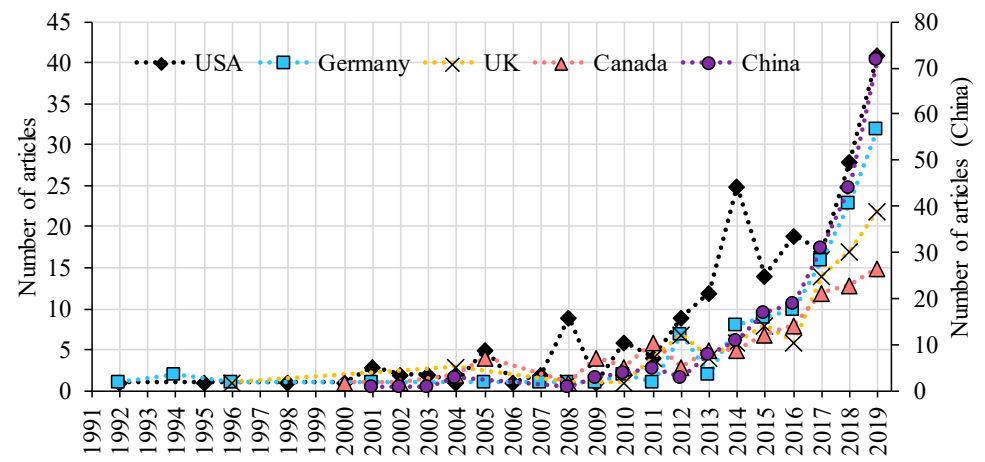

Publication year

b)

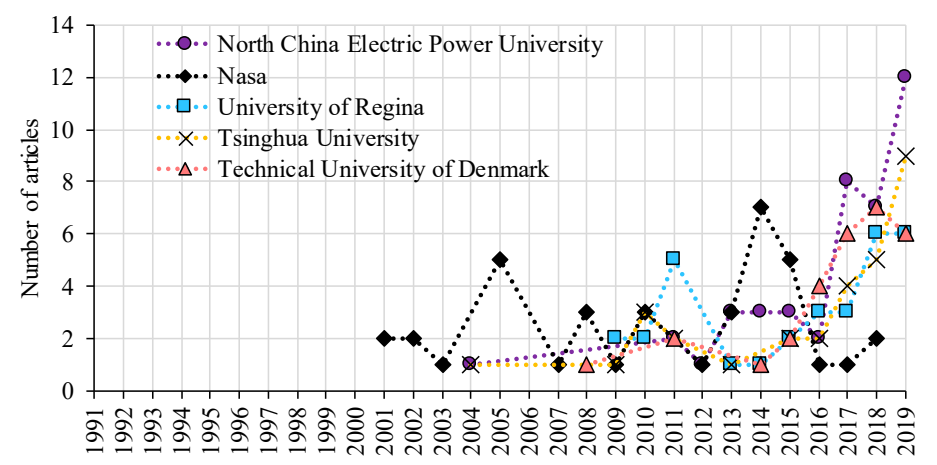

Publication year

c)

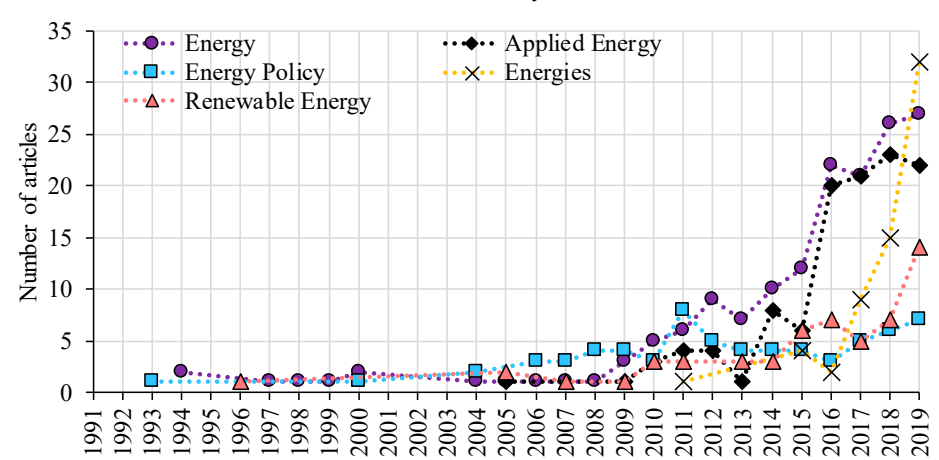

Publication year

d)

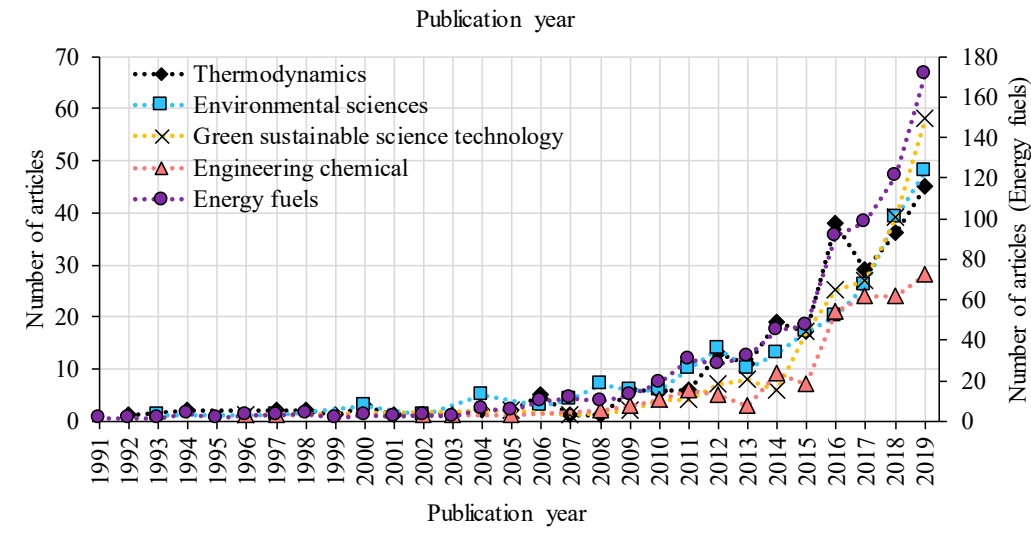

Figure 2. Annual development of publications of the top five most productive countries (a), institutes (b), journals (c) and subjects (d). For reasons of clarity, zero values are not displayed. 
In addition to the number of publications (blue gradient), Figure 1 also shows the frequency of collaborations between different countries (red lines). The wider the red line, the more authors from the linked countries have already collaborated on articles. Most collaborative publications have been produced by authors from Canada and China (37), USA and China (35), United Kingdom and China (18), Austria and Germany (11) as well as Germany and USA (11). By assigning the articles to a country via the corresponding author (cf. Table 3), the countries which frequently participate in cross-national cooperation can be shown. Switzerland and Saudi Arabia (both 53\%) have the largest share of collaborative publications, ahead of the Netherlands $(50 \%)$ and China $(48 \%)$. Authors from India ( $86 \%$ single country publications) and Italy $(80 \%)$ have the lowest share of collaborative publications.

In total, 1196 different affiliations are indicated in the publications. The top 20 most relevant of these institutions in terms of number of the publications on MESP are listed in Table 4. These institutions have been involved in $369(30 \%)$ publications so far. The distribution of publications among institutions requires more interpretation than in the case of countries, as different names or abbreviations are indicated for one institution (e.g., Swiss Federal Institute of Technology in Zurich or ETH Zurich). Among these institutions are three from China, United Kingdom and Sweden, two from Denmark, Switzerland and USA, as well as one from Austria, Canada, Croatia, Finland and India. It is noticeable that none of the institutions from Germany appear in this list, although Germany, as shown above, is one of the top five most productive countries in this field. This means that the shares of the total publications in this country are spread over several institutions. Between 1991 and 2010, most publications of the top five most productive institutions came from the National Aeronautics Space Administration, and especially from 2017 onwards, publications of the North China Electric Power University increased significantly (cf. Figure 2b). The National Aeronautics Space Administration also has the highest h-index (15) among the top 20 most productive institutions (cf. Table 4). The most relevant universities also collaborate a lot: for example, the North China Electric Power University has 16 collaborative publications with the third-ranked University of Regina. The main research areas of the top five most relevant countries and institutions are discussed in Section 3.4.

Table 4. The top 20 of the most productive institutions in terms of publications on municipal energy system planning. The percentage values refer to the total of 1235 publications.

\begin{tabular}{|c|c|c|c|c|}
\hline \multirow{2}{*}{ Institution } & \multirow{2}{*}{ Country } & \multicolumn{2}{|c|}{ Total Publications } & \multirow{2}{*}{ h-index } \\
\hline & & No. & $\%$ & \\
\hline North China Electric Power University & China & 42 & 3 & 11 \\
\hline National Aeronautics Space Administration NASA & USA & 38 & 3 & 15 \\
\hline University of Regina & Canada & 31 & 3 & 11 \\
\hline Tsinghua University & China & 30 & 2 & 12 \\
\hline Technical University of Denmark & Denmark & 29 & 2 & 12 \\
\hline Aalto University & Finland & 24 & 2 & 12 \\
\hline University of California System & USA & 24 & 2 & 11 \\
\hline Beijing Normal University & China & 23 & 2 & 11 \\
\hline University of Zagreb & Croatia & 23 & 2 & 13 \\
\hline Linkoping University & Sweden & 22 & 2 & 13 \\
\hline Aalborg University & Denmark & 21 & 2 & 14 \\
\hline Imperial College London & United Kingdom & 21 & 2 & 10 \\
\hline Chalmers University of Technology & Sweden & 20 & 2 & 9 \\
\hline Swiss Federal Institute of Technology in Zurich ETH & Switzerland & 19 & 2 & 13 \\
\hline Indian Institute of Technology & India & 17 & 1 & 10 \\
\hline KTH Royal Institute of Technology in Stockholm & Sweden & 17 & 1 & 11 \\
\hline Swiss Federal Institute of Technology in Lausanne & Switzerland & 16 & 1 & 9 \\
\hline University College London & United Kingdom & 16 & 1 & 9 \\
\hline University of London & United Kingdom & 16 & 1 & 9 \\
\hline $\begin{array}{l}\text { International Institute for Applied Systems Analysis } \\
\text { IIASA }\end{array}$ & Austria & 15 & 1 & 13 \\
\hline
\end{tabular}




\subsection{Most Relevant Sources, Authors and Articles}

The articles on MESP have been published in 241 different journals. A large proportion of the articles on MESP (65\%) are published in the top 20 most productive journals (cf. Table 5). The top five most productive journals are Energy, Applied Energy, Energy Policy, Energies and Renewable Energy. Until 2011, most of the articles were published in Energy Policy (cf. Figure 2c), which shows that MESP was initially mainly of political interest. Starting in 2012, articles were mainly published in the journal Energy, i.e., the focus changed to technical aspects of municipal energy systems. Applied Energy has the highest h-index (33) among the top 20 journals (cf. Table 5). Energies has the lowest h-index among the top five most relevant journals (10). This is not surprising, as Energies was launched in 2008 and only since 2016 has shown an exponential increase in publications on MESP (see Figure 2c). Indeed, 2019 was the first year in which most relevant articles (32) were published in Energies. A strong increase in publications on MESP since 2016 also applies to the journals Energy and Applied Energy.

Table 5. The top 20 of the most productive scientific journals in terms of publications on municipal energy system planning. The percentage values refer to the total of 1235 publications.

\begin{tabular}{cccc}
\hline Journal & \multicolumn{2}{l}{ Total Publications } & \multirow{2}{*}{ h-index } \\
\cline { 2 - 3 } & No. & $\%$ & \\
Energy & 160 & 13 & 31 \\
Applied Energy & 114 & 9 & 33 \\
Energy Policy & 67 & 5 & 25 \\
Energies & 63 & 5 & 10 \\
Renewable Energy & 56 & 5 & 18 \\
Energy Conversion and Management & 53 & 4 & 19 \\
Journal of Cleaner Production & 36 & 3 & 11 \\
International Journal of Hydrogen Energy & 33 & 3 & 13 \\
Sustainability & 31 & 3 & 8 \\
Energy and Buildings & 29 & 2 & 14 \\
Journal of Geophysical Research Atmospheres & 25 & 2 & 10 \\
Energy Strategy Reviews & 18 & 2 & 8 \\
Sustainable Cities and Society & 18 & 2 & 9 \\
Journal of Climate & 17 & 1 & 9 \\
Energy Economics & 14 & 1 & 10 \\
Energy Research E Social Science & 14 & 1 & 6 \\
Solar Energy & 14 & 1 & 8 \\
International Journal of Energy Research & 13 & 1 & 7 \\
Applied Thermal Engineering & 11 & 1 & 8 \\
Journal of Renewable and Sustainable Energy & 11 & 1 & 4 \\
\hline
\end{tabular}

All 26 authors with more than six publications on MESP are shown in Table 6. These authors, who represent only $1 \%$ of the total number of authors (3660) of MESP publications, contributed to $13.5 \%$ (167) of the articles. The following authors have the most publications and highest h-indexes; Huang GH (35 and 13), Li YP (17 and 10) and Duic N (15 and 11). As previously indicated for the journals, the longer the articles have been available, the higher the number of citations and thus the h-index tends to be. To show another measure of influence in Table 6, the total number of citations of the authors were divided by the mean publication year, which is the average of the publication years of all articles of an author. The average number of citations per year then results in a different ranking, led by Bogdanov D (224 citations per year) and Breyer C (195). The author Huang GH (115) is only seventh in this ranking despite significantly more publications. 
Table 6. The most productive authors in terms of publications on municipal energy system planning. Authors with at least six publications are shown.

\begin{tabular}{|c|c|c|c|c|c|}
\hline Journal & $\begin{array}{c}\text { Total } \\
\text { Publications }\end{array}$ & $\begin{array}{c}\text { Total } \\
\text { Citations }\end{array}$ & h-index & $\begin{array}{c}\text { Mean } \\
\text { Publication } \\
\text { Year }\end{array}$ & $\begin{array}{l}\text { Total Citations per Year } \\
\text { (Regarding Mean } \\
\text { Publication Year) }\end{array}$ \\
\hline Huang GH & 35 & 485 & 13 & 2014.8 & 115 \\
\hline Li YP & 17 & 223 & 10 & 2017.0 & 112 \\
\hline Duic N & 15 & 416 & 11 & 2014.5 & 92 \\
\hline Breyer C & 11 & 332 & 8 & 2017.3 & 195 \\
\hline Krajačić G & 11 & 338 & 9 & 2015.3 & 91 \\
\hline Bogdanov D & 10 & 314 & 7 & 2017.6 & 224 \\
\hline Lin QG & 10 & 149 & 7 & 2011.2 & 19 \\
\hline Fichtner W & 7 & 114 & 5 & 2017.7 & 88 \\
\hline Kim J & 7 & 118 & 4 & 2016.6 & 49 \\
\hline Lund $\mathrm{H}$ & 7 & 854 & 6 & 2011.7 & 117 \\
\hline Mathiesen BV & 7 & 664 & 5 & 2014.4 & 144 \\
\hline Shah N & 7 & 233 & 4 & 2014.6 & 53 \\
\hline Carmeliet J & 6 & 200 & 5 & 2016.7 & 87 \\
\hline Gebremedhin A & 6 & 177 & 6 & 2008.7 & 17 \\
\hline Henning D & 6 & 320 & 6 & 2004.2 & 22 \\
\hline Howells M & 6 & 198 & 3 & 2017.2 & 110 \\
\hline Kato S & 6 & 42 & 4 & 2014.3 & 9 \\
\hline Lund PD & 6 & 128 & 3 & 2017.3 & 75 \\
\hline Mancarella P & 6 & 133 & 6 & 2017.7 & 102 \\
\hline McKenna R & 6 & 80 & 3 & 2018.3 & 114 \\
\hline Obara S & 6 & 88 & 4 & 2010.0 & 10 \\
\hline Østergaard PA & 6 & 378 & 5 & 2014.7 & 88 \\
\hline Perera ATD & 6 & 61 & 3 & 2018.5 & 122 \\
\hline Scartezzini JL & 6 & 61 & 3 & 2018.5 & 122 \\
\hline Seixas J & 6 & 22 & 2 & 2018.5 & 44 \\
\hline Yu L & 6 & 65 & 4 & 2018.0 & 19 \\
\hline
\end{tabular}

It is not surprising that the most influential authors in terms of average citations have also written the most relevant articles so far on MESP: Lund $\mathrm{H}$ is the first author of the article with by far the most global citations [14] (420) and co-author of two other articles [15,16] in the top 20 of the most relevant articles (cf. Table 7). The former article also shows the most local citations (30) among the 1235 articles and the second highest citation rate per year (42). Local citations include all references from the 1235 articles examined in this study. The author Mathiesen BV has also contributed to the most cited article as well as another one [16] of the top 20. Among the six most locally cited references (cf. Table 8), Lund $\mathrm{H}$ and Mathiesen BV are again the authors of four articles [14,17-19]. Besides the authors Lund $\mathrm{H}$ (three articles in the top 20 of the most cited articles in Table 7) and Mathiesen BV (two), a further author, Østergaard PA (two), is represented in the top 20 more than once. Interestingly, both Mathisen BV and Østergaard PA have written their articles in cooperation with Lund $\mathrm{H}$, and all three authors are members of the Sustainable Energy Planning Research Group at the Aalborg University in Denmark. The research group thus seems to be one of the most important institutions for research on MESP. Therefore, in particular, authors from Denmark contributed to the most relevant publications on MESP (four publications), followed by the United Kingdom, Germany and Sweden (three publications each). In addition, it is striking that the first, fourth and fifth of the most frequently cited articles deal with district heating technology (cf. also Section 3.4.2). Furthermore, the majority of the top 20 most relevant articles were published in the top five most relevant journals: Applied Energy (5), Energy (4), Energy Policy (4) and Renewable Energies (4) (cf. Tables 5 and 7). 
Table 7. Most frequently cited articles among the scientific contributions on municipal energy system planning.

\begin{tabular}{|c|c|c|c|c|c|}
\hline \multirow{2}{*}{ Article Title } & \multicolumn{2}{|c|}{ Global Citations } & \multirow{2}{*}{$\begin{array}{c}\begin{array}{c}\text { Local } \\
\text { Citations }\end{array} \\
\text { No. }\end{array}$} & \multirow{2}{*}{$\begin{array}{l}\text { Publication } \\
\quad \text { Year }\end{array}$} & \multirow{2}{*}{ Journal } \\
\hline & No. & Per Year & & & \\
\hline $\begin{array}{l}\text { The role of district heating in future renewable } \\
\text { energy systems [14] }\end{array}$ & 420 & 42 & 30 & 2010 & Energy \\
\hline $\begin{array}{l}\text { Optimised model for community-based hybrid } \\
\text { energy system [20] }\end{array}$ & 252 & 19 & 15 & 2007 & Renewable Energy \\
\hline $\begin{array}{l}\text { Public acceptance of renewable energies: results } \\
\text { from case studies in Germany [21] }\end{array}$ & 230 & 19 & 2 & 2008 & Energy Policy \\
\hline $\begin{array}{l}\text { Heat distribution and the future competitiveness of } \\
\text { district heating [22] }\end{array}$ & 190 & 21 & 11 & 2011 & Applied Energy \\
\hline $\begin{array}{l}\text { Efficiency analysis of a cogeneration and district } \\
\text { energy system [23] }\end{array}$ & 178 & 12 & 4 & 2005 & $\begin{array}{l}\text { Applied Thermal } \\
\text { Engineering }\end{array}$ \\
\hline $\begin{array}{l}\text { Osemosys: the open source energy modeling system } \\
\text { an introduction to its ethos, structure and } \\
\text { development [24] }\end{array}$ & 172 & 19 & 9 & 2011 & Energy Policy \\
\hline $\begin{array}{l}\text { Feasibility study for a standalone solar-wind-based } \\
\text { hybrid energy system for application in Ethiopia [25] }\end{array}$ & 165 & 17 & 10 & 2010 & Applied Energy \\
\hline Designing microgrid energy markets [26] & 165 & 83 & 1 & 2018 & Applied Energy \\
\hline $\begin{array}{l}\text { Reviewing optimisation criteria for energy systems } \\
\text { analyses of renewable energy integration [27] }\end{array}$ & 162 & 15 & 18 & 2009 & Energy \\
\hline $\begin{array}{c}\text { A renewable energy system in Frederikshavn using } \\
\text { low-temperature geothermal energy for district } \\
\text { heating [15] }\end{array}$ & 159 & 18 & 21 & 2011 & Applied Energy \\
\hline $\begin{array}{l}\text { Integrated renewable energy systems for off grid } \\
\text { rural electrification of remote area [28] }\end{array}$ & 145 & 15 & 11 & 2010 & Renewable Energy \\
\hline $\begin{array}{l}\text { Technical feasibility study on a standalone hybrid } \\
\text { solar-wind system with pumped hydro storage for a } \\
\text { remote island in Hong Kong [29] }\end{array}$ & 145 & 24 & 9 & 2014 & Renewable Energy \\
\hline $\begin{array}{l}\text { Optimisation based design of a district energy } \\
\text { system for an eco-town in the United Kingdom [30] }\end{array}$ & 142 & 16 & 20 & 2011 & Energy \\
\hline $\begin{array}{l}\text { Dynamic modeling and simulation of a small } \\
\text { wind-fuel cell hybrid energy system [31] }\end{array}$ & 141 & 9 & 19 & 2005 & Renewable Energy \\
\hline $\begin{array}{l}\text { Evaluating energy security in the asia-pacific region: } \\
\text { a novel methodological approach [32] }\end{array}$ & 123 & 12 & 1 & 2010 & Energy Policy \\
\hline $\begin{array}{c}\text { Targeting household energy-efficiency measures } \\
\text { using sensitivity analysis [33] }\end{array}$ & 118 & 12 & 1 & 2010 & $\begin{array}{l}\text { Building Research } \\
\text { and Information }\end{array}$ \\
\hline $\begin{array}{l}\text { Large-scale integration of wind power into the } \\
\text { existing Chinese energy system [16] }\end{array}$ & 114 & 13 & 3 & 2011 & Energy \\
\hline $\begin{array}{l}\text { Least cost } 100 \% \text { renewable electricity scenarios in the } \\
\text { Australian National Electricity Market [34] }\end{array}$ & 113 & 16 & 3 & 2013 & Energy Policy \\
\hline $\begin{array}{l}\text { The economics of decarbonizing the energy } \\
\text { system - results and insights from the RECIPE } \\
\text { model intercomparison [35] }\end{array}$ & 112 & 14 & 3 & 2012 & Climatic Change \\
\hline $\begin{array}{l}\text { How to achieve a } 100 \% \text { res electricity supply for } \\
\text { Portugal? [36] }\end{array}$ & 110 & 12 & & 2011 & Applied Energy \\
\hline
\end{tabular}

Table 8. Six most frequently cited references in the articles on municipal energy system planning.

\begin{tabular}{|c|c|c|c|}
\hline \multirow{2}{*}{ Article Title } & Local Citations & \multirow[t]{2}{*}{ Publication Year } & \multirow[t]{2}{*}{ Journal } \\
\hline & Total No. & & \\
\hline $\begin{array}{c}\text { Clouds and the Earth's Radiant Energy System } \\
\text { (CERES): An Earth Observing System } \\
\text { Experiment [37] }\end{array}$ & 60 & 1996 & $\begin{array}{l}\text { Bulletin of the American } \\
\text { Meteorological Society }\end{array}$ \\
\hline $\begin{array}{c}\text { A review of computer tools for analysing the } \\
\text { integration of renewable energy into various } \\
\text { energy systems [17] }\end{array}$ & 52 & 2010 & Applied Energy \\
\hline
\end{tabular}


Table 8. Cont.

\begin{tabular}{ccccc}
\hline Article Title & Local Citations & \multirow{2}{*}{ Publication Year } & Journal \\
& Total No. & & \\
\cline { 1 - 2 } $\begin{array}{c}\text { Energy system analysis of 100\% renewable } \\
\text { energy systems - The case of Denmark in years } \\
\text { 2030 and 2050 [18] }\end{array}$ & 34 & 2009 & Energy \\
\hline $\begin{array}{c}\text { A review of urban energy system models: } \\
\text { Approaches, challenges and opportunities [38] }\end{array}$ & 32 & 2012 & $\begin{array}{c}\text { Renewable and Sustainable } \\
\text { Energy Reviews }\end{array}$ \\
\hline $\begin{array}{c}\text { 4th Generation District Heating (4GDH) [19] } \\
\text { The role of district heating in future renewable } \\
\text { energy systems [14] }\end{array}$ & 31 & 2014 & Energy \\
\hline
\end{tabular}

\subsection{Most Relevant Subjects}

In the Web of Science database, the 1235 publications are grouped into 47 different subject categories. Of these 47, the top 20 most relevant subjects by number of publications are listed in Table 9. By far the largest number of articles are assigned to the subject Energy Fuels (62\%), followed by Thermodynamics (20\%) and Environmental sciences (19\%). Thus, most publications seem to deal with technical or environmental issues, while economic analyses seem to play a minor role in MESP (Economics: 7\%). The development of the top five most relevant topics in Figure $2 \mathrm{~d}$ shows a similar trend for all topics.

Table 9. The top 20 of the most relevant subjects in terms of publications on municipal energy system planning. The percentage values refer to the total of 1235 publications.

\begin{tabular}{ccc}
\hline Subject & \multicolumn{2}{c}{ Total Publications } \\
\cline { 2 - 3 } & No. & \% \\
\hline Energy fuels & 767 & 62 \\
Thermodynamics & 250 & 20 \\
Environmental sciences & 234 & 19 \\
Green sustainable science technology & 201 & 16 \\
Engineering chemical & 141 & 11 \\
Environmental studies & 138 & 11 \\
Economics & 91 & 7 \\
Meteorology atmospheric sciences & 86 & 7 \\
Engineering environmental & 72 & 6 \\
Mechanics & 68 & 6 \\
Construction building technology & 62 & 5 \\
Engineering electrical electronic & 51 & 4 \\
Chemistry physical & 42 & 3 \\
Engineering civil & 40 & 3 \\
Electrochemistry & 36 & 3 \\
Engineering mechanical & 26 & 2 \\
Nuclear science technology & 23 & 2 \\
Remote sensing & 15 & 1 \\
Multidisciplinary sciences & 14 & 1 \\
Operations research management science & 14 & 1 \\
\hline
\end{tabular}

An analysis of the author keywords is used to cluster the topics of the 1235 publications. Table 10 shows the five largest of the resulting clusters (main topics), together with the four most frequently occurring topics (subtopics). The name of the cluster is based on the main topic, i.e., the most frequently used keyword. This grouping of keywords in clusters demonstrates which subjects are related to each other. These topics are also becoming increasingly relevant: since 2010, the number of publications on most of these topics (e.g., renewable energies, energy transition, energy storage or hybrid energy 
system) has grown more than twice as fast as the total number of publications on MESP. Furthermore, Table 11 shows the most common and therefore probably most important subjects of each of the top five most relevant countries, institutions and journals. The results of these keyword analyses are explained in more detail in the following subsections.

Table 10. Most important topics and subtopics in publications on municipal energy system planning. The percentage values refer to the total of 1235 publications.

\begin{tabular}{|c|c|c|c|}
\hline & \multirow{2}{*}{ Main Topics and Subtopics } & \multicolumn{2}{|c|}{ Number of Publications } \\
\hline & & No. & $\%$ \\
\hline \multicolumn{2}{|c|}{ Renewable energy } & 359 & 29 \\
\hline & Renewable energy & 99 & 8 \\
\hline & Optimization & 71 & 6 \\
\hline & Hybrid energy system & 51 & 2 \\
\hline & Energy efficiency & 22 & 2 \\
\hline \multirow[t]{5}{*}{ Energy system } & & 187 & 15 \\
\hline & Energy system & 43 & 4 \\
\hline & Energy transition & 37 & 3 \\
\hline & Uncertainty & 31 & 3 \\
\hline & Climate change & 20 & 2 \\
\hline \multicolumn{2}{|l|}{ District heating } & 186 & 15 \\
\hline & District heating & 39 & 3 \\
\hline & Energy & 22 & 2 \\
\hline & Biomass & 19 & 2 \\
\hline & Sustainability & 17 & 1 \\
\hline \multirow[t]{5}{*}{ Cogeneration } & & 120 & 10 \\
\hline & Cogeneration & 18 & 2 \\
\hline & Combined heat and power & 17 & 1 \\
\hline & Fuel cell & 17 & 1 \\
\hline & Distributed energy system & 16 & 1 \\
\hline \multirow[t]{5}{*}{ Energy storage } & & 95 & 8 \\
\hline & Energy storage & 30 & 2 \\
\hline & Energy planning & 20 & 2 \\
\hline & Urban energy system & 18 & 1 \\
\hline & Energy hub & 14 & 1 \\
\hline
\end{tabular}

Table 11. Most important topics in publications on municipal energy system planning in the top five relevant countries, institutions and journals. The percentage values refer to the total number of publications of the respective country, institution or journal.

\begin{tabular}{cccc}
\hline \multirow{2}{*}{ Country, Institution or Journal } & Main Topics & \multicolumn{2}{c}{ Number of Publications } \\
\cline { 2 - 4 } & & No. & $\%$ \\
\hline \multirow{2}{*}{ China } & Uncertainty & 21 & 9 \\
& Renewable energy & 15 & 7 \\
USA & Renewable energy & 10 & 5 \\
& Optimization & 7 & 3 \\
Germany & Renewable energy & 14 & 12 \\
& Energy transition & 9 & 10 \\
United Kingdom & Renewable energy & 6 & 6 \\
& Energy Storage & 12 & 13 \\
\hline \multirow{2}{*}{ Canada } & Uncertainty & 10 & 11 \\
\hline
\end{tabular}


Table 11. Cont.

\begin{tabular}{cccc}
\hline \multirow{2}{*}{ Country, Institution or Journal } & Main Topics & Number of Publications \\
\cline { 2 - 4 } & & No. & $\%$ \\
\hline North China Electric Power & Uncertainty & 17 & 40 \\
University & Planning & 6 & 14 \\
NASA & Remote sensing & 2 & 5 \\
University of Regina & Uncertainty & 11 & 35 \\
Tsinghua University & Renewable energy & 6 & 19 \\
Technical University of & Energy hub/integrated energy system/uncertainty & 3 & 10 \\
Denmark & Energy modelling/GIS/heat savings/renewable energy & 3 & 10 \\
Energy & Renewable energy & 12 & 8 \\
Applied Energy & District heating & 7 \\
Energy Policy & District heating/renewable energy & 9 & 8 \\
Energies & District heating & 7 \\
Renewable Energy & Energy system model/renewable energy & 4 & 6 \\
& Energy transition & 7 \\
\end{tabular}

\subsubsection{Renewable Energy}

As shown earlier, MESP is strongly related to the development of decentralized renewable energies. It is therefore not surprising that renewable energy is the most common keyword (in 8\% of the 1235 publications, cf. Table 10). Additionally, in publications from the USA, Germany and the United Kingdom, the Technical University of Denmark as well as in the journals Energy, Applied Energy and Renewable Energy, it is the most relevant keyword in studies on MESP (cf. Table 11).

The second most frequent keyword, optimization (6\%, cf. Table 10), is also particularly relevant for authors from USA (cf. Table 11). The review by Scheller and Bruckner [5] already demonstrated that energy system optimization models are particularly relevant to support municipal decision makers with regard to MESP. Optimization and renewable energy is also relevant when it comes to hybrid energy systems: these energy systems, which consist of renewable and conventional energy sources, are often used to supply electricity to remote rural communities located far from the national power grid [39]. In four $[20,25,29,31]$ of the top 20 most relevant publications (cf. Section 3.3), such hybrid energy systems are examined and in two [25,31] of these four articles, the energy system planning tool HOMER is applied. HOMER is also one of the most important topics on MESP in the journal Renewable Energy (cf. Table 11). Furthermore, in energy systems with a high penetration of volatile renewable energies, the reliability of the energy supply often decreases, which makes energy efficiency measures necessary [40].

\subsubsection{Energy System}

The energy transition that has been present in recent years due to climate change is also particularly relevant to the local municipal level (3\%, cf. Table 10). The German energy transition (Energiewende) has thereby attracted a great amount of attention [41]. Consequently, energy transition is the second most frequent keyword in German publications on MESP (cf. Table 11). Since an energy transition always involves an energy system, the link between these two topics is obvious.

When designing municipal energy systems, uncertainties such as the stochastic nature of renewable energies or unknown global energy outlooks can lead to suboptimal design decisions [42]. This explains the importance of uncertainty for MESP (cf. Table 10), which is the most relevant subject for two of the top five countries (China and Canada) and two of the top five institutions (North China Electric Power University and University of Regina, cf. Table 11). As already shown in Section 3.2, most cross-country collaborations are between China and Canada (37). The North China Electric Power University and 
the University of Regina have also collaborated on 16 publications. In these collaborations, the subject of uncertainty seems to be a central theme.

\subsubsection{District Heating}

The number of people living in cities and municipalities will rise sharply by 2050. It is therefore particularly important to design sustainable local energy systems [43]. If implemented correctly, the base load capable technology biomass can offer significant contributions toward sustainable development and mitigating greenhouse gas emissions [44]. Thereby, for example, the (excess) heat energy of biomass plants can be used to decarbonize residential heating through district heating networks [45]. With 39 publications on this topic (cf. Table 10), district heating seems to be an emerging and very important technology for the energy transition at the municipal level. Even three of the top five most cited articles on MESP [14,22,23] (cf. Section 3.3) deal with this subject. Since 2016, there have always been at least six articles on this topic, including the last nine in 2019: [46-54]. Furthermore, the top five of the most relevant journals increasingly deal with district heating in studies on MESP: most frequent subject in Energy Policy and Applied Energy and second most frequent subject in Energy as well as Energies (cf. Table 11). Only in the fifth-ranked journal Renewable Energy was district heating not among the top topics. District heating is the technology that is most often in focus in these journals, as well as in all publications on MESP (cf. Table 10). The great importance of district heating in the scientific community is also reflected in its practical implementation: By the end of 2015, more than $50 \%$ of heat demand was already covered by district heating in five European countries (Iceland 92\%, Lithuania 67\%, Latvia 64\%, Denmark 61\% and Estonia 54\%) [55].

\subsubsection{Cogeneration and Energy Storage}

Due to a high penetration of renewable energies, not only uncertainties, but also base-load-capable technologies or technologies that make the energy system more flexible, become more and more essential. Cogeneration systems, such as combined heat and power units, which produce both electrical and thermal energy from one primary source, are a promising and energy efficient technology to meet the energy needs of urban energy systems or distributed energy systems such as energy hubs. An energy hub represents the concept of the integration of different forms of energy, as well as relevant interface equipment and converters with each other in operation and expansion plans of distributed energy systems [56]. Cogeneration technologies can also be based on renewable energies, like the above mentioned biomass [57]. In addition to this base-load capable technology, alternative measures, such as short-term (batteries) or long-term (fuel cells combined with hydrogen storage) energy storages, can be used to make the energy system more flexible by storing and discharging energy from renewable energy sources [58]. Cogeneration systems and energy storage systems are also often studied together in one energy system (e.g., [59]). These subjects are covered in about $18 \%$ of the publications on MESP (cf. Table 10).

\subsection{Limitations of This Study}

As all review studies, the present bibliometric analysis depends on the search query (cf. Table 1) in the literature database. Since many different keywords are used to describe MESP, it is hardly possible to cover the entire research area in one review study. For example, adding the often-used keyword local to the search query would have increased the number of results to $1506(+22 \%)$. However, the decision against this keyword was made, since it is used in many research areas. For example, this would have resulted in two new articles $[60,61]$ in the top five most cited publications, which are not directly related to MESP and are using the terms local air pollution or local optimization. However, it has to be assumed that even the search terms finally used result in articles that are not necessarily related to MESP. Therefore, the present review should typically not be considered as a complete overview for MESP. It is likely that some of the articles on local sustainable energy action plans are now missing in this review. Nevertheless, the trends in this research area are expected to be adequately reflected by this review. 


\section{Summary and Conclusions}

In the context of the energy transition and the increasing penetration of renewable energies, energy system planning is becoming increasingly relevant for decentralized systems. In association, the contributions of municipalities and cities to the decarbonization of the global energy system are of growing importance. Consequently, the number of publications on municipal energy system planning has increased exponentially between 1991 and 2019, amounting to 1235 at the time of this analysis. This requires a study of the corpus of literature to show the status quo and trends in research on municipal energy system planning. The present study therefore uses a bibliometric analysis, supported by the literature database Web of Science and the R-tool bibliometrix.

The study shows that China is the most important contributor with 225 articles, followed by the USA (205), whose total number of publications also has the highest h-index (33), and Germany (120). In addition, authors from China undertake the most cross-country collaborations: the top value is represented by 37 collaborations with authors from Canada, focusing mainly on uncertainties in municipal energy systems planning.

Among the institutions, the North China Electric Power University is responsible for most articles (42), followed by the National Aeronautics Space Administration with 38 articles and the highest h-index (15), as well as the University of Regina with 31 publications. Sixteen of the 37 co-operations between China and Canada were conducted between the North China Electric Power University and the University of Regina. Furthermore, the Sustainable Energy Planning Research Group of the Aalborg University in Denmark led by Henrik Lund seems to play a central role in municipal energy system planning according to the global and local citations of articles.

The core journals on municipal energy system planning are Energy, Applied Energy, Energy Policy, Energies and Renewable Energy, which published 37\% of the 1235 articles. By far the most articles were published by Energy, while Applied Energy has the highest h-index (33). In addition, the journal Energies has experienced the strongest increase in the number of publications in recent years and published the most articles on the subject for the first time in 2019.

The most relevant subject among the Web of Science categories is energy fuels, while the analysis of the Author keywords shows that municipal energy system planning focuses mainly on renewable energies, optimization and hybrid energy systems. These topics are also becoming increasingly relevant: since 2010, the share of publications on these topics in the total body of literature on municipal energy system planning has doubled. Furthermore, district heating seems to be a core research topic in municipal energy system planning: two of the most relevant authors (Henrik Lund and Brian Vad Mathiesen) address this subject and three of the top five most cited articles focus on district heating. It is also the most frequently stated technology in the journals Energy, Applied Energy, Energy Policy and Energies as well as among the author keywords, and thus seems to be a crucial technology for the energy transition at the municipal level.

The present bibliometric analysis demonstrates global research trends in municipal energy system planning. This study can therefore support researchers, local stakeholders, energy producers, energy suppliers, service providers, and local policy makers in identifying the relevant issues regarding the expanding and transforming municipal energy system planning research area. Policy makers could react to the increasing relevance of technologies, such as renewable energies and district heating at the local level, with appropriate subsidy mechanisms to facilitate their implementation.

Funding: This research received no external funding. The APC was funded by the KIT-Publication Fund of the Karlsruhe Institute of Technology.

Acknowledgments: I acknowledge support by the KIT-Publication Fund of the Karlsruhe Institute of Technology. I would also like to thank my PhD supervisor Wolf Fichtner for all the constructive discussions in the past years, and my former group leader, mentor and friend Russell McKenna, who introduced me to good scientific practice and from whom I learned everything about research. Furthermore, I thank the three anonymous reviewers, who provided valuable comments on earlier versions of this manuscript. The usual disclaimer applies.

Conflicts of Interest: The author declares no conflict of interest. 


\section{References}

1. BMWi. Abkommen von Paris. Available online: https:/www.bmwi.de/Redaktion/DE/Artikel/Industrie/ klimaschutz-abkommen-von-paris.html (accessed on 4 February 2020).

2. International Renewable Energy Agency. Renewable Energy Statistics 2019. Available online: https: //www.irena.org/publications/2019/Jul/Renewable-energy-statistics-2019 (accessed on 4 February 2020).

3. trend:research. Eigentürmerstruktur: Erneuerbare Energien. Entwicklung der Akteursvielfalt, Rolle der Energieversorger, Ausblick bis 2020. Available online: https://www.trendresearch.de/studie.php?s=672 (accessed on 5 March 2020).

4. Bringault, A.; Eisermann, M.; Lacassagne, S. Cities Heading towards 100\% Renewable Energy. Available online: https://energy-cities.eu/wp-content/uploads/2018/11/publi_100pourcent_final-web_en.pdf (accessed on 4 February 2020).

5. Scheller, F.; Bruckner, T. Energy system optimization at the municipal level: An analysis of modeling approaches and challenges. Renew. Sustain. Energy Rev. 2019, 105, 444-461. [CrossRef]

6. Pablo-Romero, M.d.P.; Sánchez-Braza, A.; Manuel González-Limón, J. Covenant of Mayors: Reasons for Being an Environmentally and Energy Friendly Municipality. Rev. Policy Res. 2015, 32, 576-599. [CrossRef]

7. Kona, A.; Bertoldi, P.; Kılkış, Ş. Covenant of Mayors: Local Energy Generation, Methodology, Policies and Good Practice Examples. Energies 2019, 12, 985. [CrossRef]

8. Bertoldi, P.; Kona, A.; Rivas, S.; Dallemand, J.F. Towards a global comprehensive and transparent framework for cities and local governments enabling an effective contribution to the Paris climate agreement. Curr. Opin. Environ. Sustain. 2018, 30, 67-74. [CrossRef]

9. Aria, M.; Cuccurullo, C. bibliometrix: An R-tool for comprehensive science mapping analysis. J. Informetr. 2017, 11, 959-975. [CrossRef]

10. Du, H.; Li, N.; Brown, M.A.; Peng, Y.; Shuai, Y. A bibliographic analysis of recent solar energy literatures: The expansion and evolution of a research field. Renew. Energy 2014, 66, 696-706. [CrossRef]

11. Hirsch, J.E. An index to quantify an individual's scientific research output. Proc. Natl. Acad. Sci. USA 2005, 102, 16569-16572. [CrossRef] [PubMed]

12. Zeng, M.; Li, C.; Zhou, L. Progress and prospective on the police system of renewable energy in China. Renew. Sustain. Energy Rev. 2013, 20, 36-44. [CrossRef]

13. Hake, J.-F.; Fischer, W.; Venghaus, S.; Weckenbrock, C. The German Energiewende-History and status quo. Energy 2015, 92, 532-546. [CrossRef]

14. Lund, H.; Möller, B.; Mathiesen, B.V.; Dyrelund, A. The role of district heating in future renewable energy systems. Energy 2010, 35, 1381-1390. [CrossRef]

15. Østergaard, P.A.; Lund, H. A renewable energy system in Frederikshavn using low-temperature geothermal energy for district heating. Appl. Energy 2011, 88, 479-487. [CrossRef]

16. Liu, W.; Lund, H.; Mathiesen, B.V. Large-scale integration of wind power into the existing Chinese energy system. Energy 2011, 36, 4753-4760. [CrossRef]

17. Connolly, D.; Lund, H.; Mathiesen, B.V.; Leahy, M. A review of computer tools for analysing the integration of renewable energy into various energy systems. Appl. Energy 2010, 87, 1059-1082. [CrossRef]

18. Lund, H.; Mathiesen, B.V. Energy system analysis of $100 \%$ renewable energy systems-The case of Denmark in years 2030 and 2050. Energy 2009, 34, 524-531. [CrossRef]

19. Lund, H.; Werner, S.; Wiltshire, R.; Svendsen, S.; Thorsen, J.E.; Hvelplund, F.; Mathiesen, B.V. 4th Generation District Heating (4GDH). Energy 2014, 68, 1-11. [CrossRef]

20. Ashok, S. Optimised model for community-based hybrid energy system. Renew. Energy 2007, 32, 1155-1164. [CrossRef]

21. Zoellner, J.; Schweizer-Ries, P.; Wemheuer, C. Public acceptance of renewable energies: Results from case studies in Germany. Energy Policy 2008, 36, 4136-4141. [CrossRef]

22. Persson, U.; Werner, S. Heat distribution and the future competitiveness of district heating. Appl. Energy 2011, 88, 568-576. [CrossRef]

23. Rosen, M.A.; Le, M.N.; Dincer, I. Efficiency analysis of a cogeneration and district energy system. Appl. Therm. Eng. 2005, 25, 147-159. [CrossRef] 
24. Howells, M.; Rogner, H.; Strachan, N.; Heaps, C.; Huntington, H.; Kypreos, S.; Hughes, A.; Silveira, S.; DeCarolis, J.; Bazillian, M.; et al. OSeMOSYS: The Open Source Energy Modeling System. Energy Policy 2011, 39, 5850-5870. [CrossRef]

25. Bekele, G.; Palm, B. Feasibility study for a standalone solar-wind-based hybrid energy system for application in Ethiopia. Appl. Energy 2010, 87, 487-495. [CrossRef]

26. Mengelkamp, E.; Gärttner, J.; Rock, K.; Kessler, S.; Orsini, L.; Weinhardt, C. Designing microgrid energy markets. Appl. Energy 2018, 210, 870-880. [CrossRef]

27. Østergaard, P.A. Reviewing optimisation criteria for energy systems analyses of renewable energy integration. Energy 2009, 34, 1236-1245. [CrossRef]

28. Kanase-Patil, A.B.; Saini, R.P.; Sharma, M.P. Integrated renewable energy systems for off grid rural electrification of remote area. Renew. Energy 2010, 35, 1342-1349. [CrossRef]

29. Ma, T.; Yang, H.; Lu, L.; Peng, J. Technical feasibility study on a standalone hybrid solar-wind system with pumped hydro storage for a remote island in Hong Kong. Renew. Energy 2014, 69, 7-15. [CrossRef]

30. Weber, C.; Shah, N. Optimisation based design of a district energy system for an eco-town in the United Kingdom. Energy 2011, 36, 1292-1308. [CrossRef]

31. Khan, M.J.; Iqbal, M.T. Dynamic modeling and simulation of a small wind-fuel cell hybrid energy system. Renew. Energy 2005, 30, 421-439. [CrossRef]

32. Vivoda, V. Evaluating energy security in the Asia-Pacific region: A novel methodological approach. Energy Policy 2010, 38, 5258-5263. [CrossRef]

33. Firth, S.K.; Lomas, K.J.; Wright, A.J. Targeting household energy-efficiency measures using sensitivity analysis. Build. Res. Inf. 2010, 38, 25-41. [CrossRef]

34. Elliston, B.; MacGill, I.; Diesendorf, M. Least cost 100\% renewable electricity scenarios in the Australian National Electricity Market. Energy Policy 2013, 59, 270-282. [CrossRef]

35. Luderer, G.; Bosetti, V.; Jakob, M.; Leimbach, M.; Steckel, J.C.; Waisman, H.; Edenhofer, O. The economics of decarbonizing the energy system-Results and insights from the RECIPE model intercomparison. Clim. Chang. 2012, 114, 9-37. [CrossRef]

36. Krajačić, G.; Duić, N.; Carvalho, M.d.G. How to achieve a 100\% RES electricity supply for Portugal? Appl. Energy 2011, 88, 508-517. [CrossRef]

37. Wielicki, B.A.; Barkstrom, B.R.; Harrison, E.F.; Lee, R.B.; Louis Smith, G.; Cooper, J.E. Clouds and the Earth's Radiant Energy System (CERES): An Earth Observing System Experiment. Bull. Amer. Meteor. Soc. 1996, 77, 853-868. [CrossRef]

38. Keirstead, J.; Jennings, M.; Sivakumar, A. A review of urban energy system models: Approaches, challenges and opportunities. Renew. Sustain. Energy Rev. 2012, 16, 3847-3866. [CrossRef]

39. Kaundinya, D.P.; Balachandra, P.; Ravindranath, N.H. Grid-connected versus stand-alone energy systems for decentralized power-A review of literature. Renew. Sustain. Energy Rev. 2009, 13, 2041-2050. [CrossRef]

40. Dhakouani, A.; Znouda, E.; Bouden, C. Impacts of energy efficiency policies on the integration of renewable energy. Energy Policy 2019, 133, 110922. [CrossRef]

41. Moss, T.; Becker, S.; Naumann, M. Whose energy transition is it, anyway? Organisation and ownership of the Energiewende in villages, cities and regions. Local Environ. 2014, 20, 1547-1563. [CrossRef]

42. Mavromatidis, G.; Orehounig, K.; Carmeliet, J. A review of uncertainty characterisation approaches for the optimal design of distributed energy systems. Renew. Sustain. Energy Rev. 2018, 88, 258-277. [CrossRef]

43. Kammen, D.M.; Sunter, D.A. City-integrated renewable energy for urban sustainability. Science 2016, 352, 922-928. [CrossRef]

44. Walter, A.; Seabra, J.E.A.; Machado, P.G.; de Barros Correia, B.; de Oliveira, C.O.F. Sustainability of Biomass. In Biomass and Green Chemistry: Building a Renewable Pathway; Vaz, S., Jr., Ed.; Springer: Berlin/Heidelberg, Germany, 2018; pp. 191-219. ISBN 978-3-319-66736-2.

45. Weinand, J.M.; McKenna, R.; Karner, K.; Braun, L.; Herbes, C. Assessing the potential contribution of excess heat from biogas plants towards decarbonising residential heating. J. Clean. Prod. 2019, 238, 117756. [CrossRef]

46. Weinand, J.M.; Kleinebrahm, M.; McKenna, R.; Mainzer, K.; Fichtner, W. Developing a combinatorial optimisation approach to design district heating networks based on deep geothermal energy. Appl. Energy 2019, 251, 113367. [CrossRef] 
47. Weinand, J.M.; McKenna, R.; Kleinebrahm, M.; Mainzer, K. Assessing the contribution of simultaneous heat and power generation from geothermal plants in off-grid municipalities. Appl. Energy 2019, 255, 113824. [CrossRef]

48. van der Heijde, B.; Vandermeulen, A.; Salenbien, R.; Helsen, L. Integrated Optimal Design and Control of Fourth Generation District Heating Networks with Thermal Energy Storage. Energies 2019, 12, 2766. [CrossRef]

49. Kim, M.-H.; Kim, D.; Heo, J.; Lee, D.-W. Techno-economic analysis of hybrid renewable energy system with solar district heating for net zero energy community. Energy 2019, 187, 115916. [CrossRef]

50. Sandberg, E.; Kirkerud, J.G.; Trømborg, E.; Bolkesjø, T.F. Energy system impacts of grid tariff structures for flexible power-to-district heat. Energy 2019, 168, 772-781. [CrossRef]

51. Popovski, E.; Aydemir, A.; Fleiter, T.; Bellstädt, D.; Büchele, R.; Steinbach, J. The role and costs of large-scale heat pumps in decarbonising existing district heating networks-A case study for the city of Herten in Germany. Energy 2019, 180, 918-933. [CrossRef]

52. Blomqvist, S.; La Fleur, L.; Amiri, S.; Rohdin, P.; Ödlund, L. The Impact on System Performance When Renovating a Multifamily Building Stock in a District Heated Region. Sustainability 2019, 11, 2199. [CrossRef]

53. Casisi, M.; Costanzo, S.; Pinamonti, P.; Reini, M. Two-Level Evolutionary Multi-objective Optimization of a District Heating System with Distributed Cogeneration. Energies 2019, 12, 114. [CrossRef]

54. Rehman, H.u.; Hirvonen, J.; Kosonen, R.; Sirén, K. Computational comparison of a novel decentralized photovoltaic district heating system against three optimized solar district systems. Energy Convers. Manag. 2019, 191, 39-54. [CrossRef]

55. Sayegh, M.A.; Danielewicz, J.; Nannou, T.; Miniewicz, M.; Jadwiszczak, P.; Piekarska, K.; Jouhara, H. Trends of European research and development in district heating technologies. Renew. Sustain. Energy Rev. 2017, 68, 1183-1192. [CrossRef]

56. Sadeghi, H.; Rashidinejad, M.; Moeini-Aghtaie, M.; Abdollahi, A. The energy hub: An extensive survey on the state-of-the-art. Appl. Therm. Eng. 2019, 161, 114071. [CrossRef]

57. Raj, N.T.; Iniyan, S.; Goic, R. A review of renewable energy based cogeneration technologies. Renew. Sustain. Energy Rev. 2011, 15, 3640-3648. [CrossRef]

58. Gallo, A.B.; Simões-Moreira, J.R.; Costa, H.; Santos, M.M.; Moutinho dos Santos, E. Energy storage in the energy transition context: A technology review. Renew. Sustain. Energy Rev. 2016, 65, 800-822. [CrossRef]

59. Stoppato, A.; Benato, A.; Destro, N.; Mirandola, A. A model for the optimal design and management of a cogeneration system with energy storage. Energy Build. 2016, 124, 241-247. [CrossRef]

60. Lozano, M.A.; Valero, A. Theory of the exergetic cost. Energy 1993, 18, 939-960. [CrossRef]

61. Ball, M.; Wietschel, M. The future of hydrogen-opportunities and challenges. Int. J. Hydrog. Energy 2009, 34, 615-627. [CrossRef]

(C) 2020 by the author. Licensee MDPI, Basel, Switzerland. This article is an open access article distributed under the terms and conditions of the Creative Commons Attribution (CC BY) license (http://creativecommons.org/licenses/by/4.0/). 